\title{
ОРГАНІЗАЦІЯ МЕРЕЖЕВОГО НАВЧАННЯ В МЕДИЦИНІ
}

\author{
В. В. Краснов, М. М. Жирок \\ Національна медична академія післядипломної освіти імені П. Л. Шупика
}

\begin{abstract}
Представлено основні принципи організації мережевого навчання в закладах медичної освіти. Показано результати експериментів, що свідчать про низьку результативність мережевого навчання без попереднього формування навиків командної взаємодії.
\end{abstract}

Ключові слова: мережеве навчання, командна взаємодія.

\section{ОРГАНИЗАЦИЯ СЕТЕВОГО ОБУЧЕНИЯ В МЕДИЦИНЕ}

\author{
В. В. Краснов, М. Н. Жирок \\ Национальная медицинская академия последипломного образования имени П. Л. Шупика
}

\begin{abstract}
Представлены основные принципы организации сетевого обучения в учреждениях медицинского образования. Предложен процесс организации сетевого обучения, который представляет собой такую последовательность: формирование у слушателей мотивации и навыков результативной коммуникации в группе; обучение использованию инструментария, методологии и методик дистанционного взаимодействия для решения учебных задач; реальная удаленная работа под наблюдением преподавателя; самостоятельная дистанционная, взаимодействие. Показан ы результаты экспериментов, которые свидетельствуют, что без предварительного формирования навыков командного взаимодействия результативность сетевого обучения будет низкой.
\end{abstract}

Ключевые слова: сетевое обучение, командное взаимодействие.

\section{ORGANIZATION OF NETWORKED LEARNING IN MEDICINE}

\author{
V. V. Krasnov, M. M. Zhyrok \\ National Medical Academy of Postgraduate Education by P. L. Shupyk
}

\begin{abstract}
The basic principles of organization of a network learning in institutions of medical education were set. We propose the organizing process of network learning, which is the following sequence: formation of the students motivation and skills of effective communication in the group; training in the use of tools, methodologies and techniques for distance communications solutions to educational problems; real distant work under the supervision of a teacher; independent remote interaction. The results of experiments show that without the formation of team interaction skills training effectiveness of the network is low.
\end{abstract}

Key words: online learning, teamwork.

Вступ. Мережеве навчання (МH) є сформованим напрямком освіти, що побудований на принципах «горизонтальної» або «децентралізованої» самоорганізації суб'єктів навчання. Під МН розуміють парадигму навчальної діяльності, яка базується на ідеї масового співробітництва, ідеології відкритих освітніх ресурсів, у поєднанні з мережевою організацією взаємодії учасників навчального процесу.

Згідно 3 дослідженнями групи Ланкастерського університету, в МН інформаційні та комунікаційні технології використовуються для сприяння встановленню зв'язків: між тими, хто навчається, між слухачами та викладачами (т'юторами), між навчальним співтовариством і його навчальними ресурсами, що дозволяє слухачам поглиблювати свої знання та розширювати можливості, які вони вважають важливими і які можуть самостійно контролювати [1]. Тобто в МН безпосередньо відсутні викладачі, функції яких розподілені між самими учасниками навчання. Іншими словами, учасники взаємного навчання, забезпеченого інформаційно-комунікаційними технологіями (IKT), здійснюють самостійне «безперервне спільне виробництво загального навчального середовища» та «створення навчального контексту, необхідного і достатнього для їх самоосвіти».

МН засноване на визнанні потенціалу і можливостей комп'ютерних технологій та спільного (групового) навчання (collaborative learning), що передбачає

(C) В. В. Краснов, М. М. Жирок 
колективні інтелектуальні зусилля учасників навчального процесу (слухачів і викладачів), коли групи слухачів працюють разом для розуміння завдань, пошуку смислів, вирішення проблем, створення контенту і досягнення результатів [2]. Крім того, спільне навчання припускає, що люди працюють в групах над спільним завданням чи проблемою, до вирішення якої вони роблять загальний (рівний) внесок.

У МН інформаційні технології опосередковують не просто взаємодію слухачів, а їх роботу в режимі навчального співтовариства зі спільного створення навчальних ресурсів, розділяючи між собою зони відповідальності [3].

Але існує проблемна область, яка полягає у тому, що МН в різних університетах показує різну результативність, а також, якщо слухачеві надається можливість використовувати інформаційні технології для спільної роботи, він віддає перевагу «живій» взаємодії.

У медицині вміння працювати в колективі є дуже проблемним питанням. Іноді помилково медицина вважається професією одинаків, коли всю відповідальність за прийняття рішення несе лікуючий лікар. При цьому не береться до уваги те, що лікар, до прийняття рішення, повинен співпрацювати з командами інших професіоналів, налагодити роботу яких повинен саме він.

Мета дослідження. Обгрунтувати основні підходи до організації мережевого навчання.

При організації МН ключовим є вміння учасників навчання організувати взаємодію для генерування проміжного продукту (правильно структурованих навчальних матеріалів) і кінцевого продукту (середовища, яке підтримує і забезпечує набуття професійних навичок). Тобто чіткого розмежування між МН і спільним (колаборативним) навчанням немає. Можна стверджувати, що спільне навчання для підвищення ефективності застосовує IКТ і в результаті набуває форми МН.

Колаборативне навчання є збірним образом різних освітніх підходів, коли ті, хто навчається, працюють в групі для пошуку порозуміння, вирішення проблем, створення продуктів навчання. Кожен створений ними новий навчальний продукт «вбудовується» в спільний навчальний когнітивний простір.

Результативність МН грунтується на ряді властивостей, якими повинна володіти група: спільне прийняття рішень, здорова критика, налаштованість на загальний результат, взаємна мотивація і допомога, прийняття відмінностей учасників групи. Ми вважаємо, що подібні властивості не можуть сформуватися в непідготовленій групі, в якій немає навичок командної взаємодії.
Отже, була сформульована гіпотеза дослідження - попереднє формування у лікарів-інтернів компетенцій групової роботи, створення мотивації до кооперативної взаємодії при вирішенні навчальних завдань дасть можливість створити умови для їх групової роботи в період дистанційного навчання та самостійної роботи.

Матеріали та методи. В дослідженні брали участь 2 групи лікарів-інтернів 3 педіатрії чисельністю по 20 осіб кожна. Методи впливу: навчальні тренінги, мережеві технології навчання. Методи дослідження: соціологічне анкетування, тестовий контроль знань. Статистичні методи обробки даних: непараметричний метод $\mathrm{c}^{2}$, порівняння незалежних сукупностей параметричними методами.

У проведених експериментах було ініційовано формування навичок співпраці в групах лікарів-інтернів при навчанні в аудиторії (без застосування мережевих технологій). Основні складові методу - 1) «круглі столи»; 2) включення емоційної взаємодії з формуванням емпатії до групи; 3) ігрове моделювання ситуацій.

В експериментальній групі проводився тренінг 3 набуття навичок співпраці. Після цього контрольній та експериментальній групам було доручено вирішення серії клінічних кейсів, які вимагали колективного збору інформації, аналізу ситуації та прийняття рішень. Головна вимога - використання мережевих технологій і заборона аудиторної взаємодії.

Результати та їх обговорення. В результаті такого навчання лікарі-інтерни експериментальної групи почали сприймати групу як єдине ціле та отримали: розвиток здатності критично мислити; набуття навичок встановлення складних діагнозів при організації роботи різних професіоналів з персональною відповідальністю кожного за загальний результат; позитивний психологічний клімат у групі; прагнення слухачів до співробітництва; розвиток емпатійної реакції, взаємопідтримки; високий рівень самоповаги, яка виявляється в емоційній врівноваженості, усвідомленні особистісної індивідуальності, прояві довіри, оптимістичному сприйнятті оточення. Після подібної підготовки значно збільшилася результативність мережевої взаємодії при вирішенні ситуативних клінічних завдань. В експериментальній групі зростало продукування навчального контенту впродовж півроку, тоді як в контрольній - групова взаємодія була епізодичною і формування контенту не відбувалося. Також в контрольній групі завдання на груповий результат не були вирішені. Дані експериментів наведено в таблиці 1. 
Таблиця 1. Результативність методології попереднього формування компетенцій колаборативної взаємодії

\begin{tabular}{|c|c|c|c|}
\hline \multirow[b]{2}{*}{ Критерій } & \multicolumn{2}{|c|}{ Групи } & \multirow[b]{2}{*}{$\mathrm{p}$} \\
\hline & $\begin{array}{l}\text { контр. } \\
(\mathrm{n}=20)\end{array}$ & $\begin{array}{l}\text { експ. } \\
(\mathrm{n}=20)\end{array}$ & \\
\hline Результати іспитів (бали; $\mathrm{M} \pm \mathrm{m}$ ) & $45 \pm 7$ & $87 \pm 12$ & $<0,05$ \\
\hline $\begin{array}{l}\text { Добровільний вибір лікарями-інтернами інформаційних технологій, що } \\
\text { забезпечують групову взаємодію (\% випадків) }\end{array}$ & 7 & 45 & $<0,01$ \\
\hline $\begin{array}{l}\text { Середній час групової дистанційної взаємодії відносно часу, виділеного } \\
\text { на самостійну підготовку (\%) }\end{array}$ & 20 & 70 & $<0,05$ \\
\hline $\begin{array}{l}\text { Взаємодія групи в завданнях, не пов'язаних із навчальним планом (годин } \\
\text { на добу; } \mathrm{M} \pm \mathrm{m})\end{array}$ & $1 \pm 0,3$ & $3 \pm 0,7$ & $<0,05$ \\
\hline
\end{tabular}

У результаті досліджень була запропонована послідовність дій щодо підвищення результативності МН у лікарів-інтернів:

1) формування у лікарів-інтернів мотивації і навичок результативної комунікації в групі;

2) навчання використанню інструментарію, методології та методик дистанційної взаємодії для вирішення навчальних завдань;

3) реальна дистанційна робота під наглядом викладача;

4) самостійна дистанційна взаємодія.

\section{Література}

1. Патаракин Е. Д. Социальные взаимодействия и сетевое обучение 2.0 / Е. Д. Патаракин. - М. : НП «Современные технологии в образовании и культуре», 2009. - 176 с.

2. Корнели Д. Парагогика: синергия самостоятельной и организованной учебной деятельности [Электронный ресурс] / Д. Корнели, Ч. Данофф ; пер. И. Травкин. - Режим
Також в результаті експериментів було виявлено, що після завершення навчання лікарі-інтерни продовжували підтримувати створене професійне мережеве співтовариство без будь-якого впливу з боку організаторів навчання.

Висновки. МН $є$ ефективною та перспективною технологією набуття професійних і професійно-соціальних компетенцій лікарями, але без попереднього навчання навикам командної взаємодії результативність МН є низькою.

доступу : http://www.connectedlearning.ru/home/ ravnogogika/1st-paper.

3. Exploring the Theory, Pedagogy and Practice of Networked Learning/L. Dirckinck-Holmfeld, V Hodgson, D. McConnell [et al.]. - XXIII - New York : Springer, 2012. - 318 p. 